\title{
PENGARUH MODEL PEMBELAJARAN PROBLEM BASED LEARNINGDAN MODEL PEMBELAJARAN KONVENSIONAL TERHADAP HASIL BELAJAR SISWA PADA MATA PELAJARANMATEMATIKA DI KELAS V SDN 068003 P.SIMALINGKAR MEDAN TAHUN PEMBELAJARAN 2018/2019
}

\section{OLEH:}

\section{VALEN ANASTASYA SITUMORANG (PGSD FKIP UNIVERSITAS KATOLIK SANTO THOMAS SU)}

\begin{abstract}
This study aims to determine the effect of using Problem Based Learning models on students' learning outcomes. This research was conducted at SDN 068003 P.Simalingkar Medan in July 2018. The subjects of research were 33 students'. The research method is a One Shot Case Study that is carried out in one class. The instrument used to collecting the data is a multiple choice test. Hypothesis testing is done using the "t-test".

The results of statistical calculations showed that the students' mathematics learning outcomes using conventional learning models included in the sufficient category with the students' mean score is 64.24 , while the learning outcomes through the Problem Based Learning model in the excellent category with the mean score is 80.90. Furthermore, hypothesis testing shows that $\mathrm{t}$ count is 83.3 and then consulted with table $\mathrm{t}$ at the significant $\alpha=0.05$ with $\mathrm{dk}=64$ is 1.67 . Therefore, the tcount obtained is greater than t table that is $83.3>1.67$ so it is proven that the null hypothesis (Ho) is rejected and the alternative hypothesis (Ha) is accepted. So it can be concluded that the Problem Based Learning model influences for the students' learning outcomes in Mathematics subjects at the fifth grade students' of SDN 068003 P.Simalingkar Medan in academic year 2018/2019. Thus, this learning model is appropriate for use in the learning process.
\end{abstract}

\section{Keywords: Problem Based Learning, Learning Outcomes}

\section{PENDAHULUAN}

\section{Latar Belakang Masalah}

Pendidikan adalah sesuatu yang universal dan berlangsung secara terus-menerus dari generasi ke generasi dimanapun berada.Pendidikan juga merupakan usaha untuk membina dan mengembangkan potensi sumber daya manusia dengan melalui berbagai kegiatan belajar mengajar yang diselenggarakan pada semua tingkat pendidikan dari mulai sekolah dasar, sekolah menengah hingga ke perguruan tinggi.

UU No.20 tahun 2003 (Hendriana dan Soemarmo 2016:6) Pendidikan Nasional bertujuan untuk mengembangkan potensi peserta didik agar menjadi manusia yang beriman dan bertakwa kepada Tuhan Yang Maha Esa, berakhlak mulia, sehat, berilmu, cakap, kreatif, mandiri, dan menjadi warga negara yang demokratis serta bertanggung 
jawab. Namun, kualitas pendidikan yang terjadi saat ini perlahan-lahan menurun hal ini dapat menyebabkan terhambatnya penyediaan sumber daya manusia untuk memenuhi kebutuhan sehari-hari maupun pengembangan bangsa di berbagai bidang. Untuk memperbaiki kualitas pendidikan saat ini, maka tindakan yang harus dilakukan salah satunya adalah dengan memperbaiki kualitas pendidikan disekolah dasar. Sebab pendidikan di sekolah dasar merupakan pendidikan dasar dari semua jenjng pendidikan ke tingkat selanjutnya.

Di Sekolah Dasar terdapat beberapa mata pelajaran yang harus dikuasai siswa, salah satunya adalah Matematika. Matematika memberikan kontribusi positif dalam mencerdaskan kehidupan bangsa Indonesia bahkan terhadap perkembangan ilmu Matematika memiliki peranan sangat penting. Agar dapat mengikuti perkembangan ilmu Matematika diperlukan keterampilan intelektual yang memadai, yaitu kemampuan bernalar, berpikir sistematis, cermat, kritis dan kreatif. Keterampilan intelektual dapat dikembangkan melalui pembelajaran Matematika, karena Matematika memiliki struktur dan keterkaitan antar konsepnya, sehingga membuat siswa terampil berpikir rasional.

Hudojo (2017: 37) mengatakan Matematika merupakan suatu ilmu yang cara bernalarnya deduktif formal dan abstrak, harus diberikan kepada siswa sekolah dasar yang cara berfikirnya masih pada tahap operasi konkret. Oleh sebab itu, mengingat Matematika cara bernalarnya deduktif formal dan abstrak, maka guru diharapkan lebih kreatif dan inovatif dalam memilih model pembelajaran agar siswa cepat lebih memahami materi dan hasil belajar Matematika.

Berdasarkan hasil observasi di kelas V SDN 068003 P.Simalingkar Medan dalam pembelajaran Matematika, masih sering ditemukan ketidakmaksimalan terhadap hasil belajar yang diperoleh siswa diantaranya adalah: 1)Beberapa siswa masih sulit memahami materi pembelajaran Matematika, 2) Sebagian guru kurang memilih dan menerapkan model pembelajaran yang dapat mengaktifkan siswa dalam kegiatan belajar mengajar, 3)Hanya sebagian guru mengajar menggunakan media, 4) Rendahnya hasil belajar siswa dalam pembelajaran Matematika.

Beberapa siswa masih sulit memahami materi pembelajaran Matematika. Dikarenakan pemahaman materi pembelajaranMatematikanya masih rendah sehingga beberapa siswa masih mengalami kesulitan. Kesulitan siswa dalam memahami materi bangun datardisebabkan karena kurang mengingat atau mengahafal rumus-rumus 
tentang materi bangun datar, sehingga siswa kesulitan dalam menjawab soal tentang bangun datar.

Namun, berhasil tidaknya suatu keberhasilan belajar siswaterhadap pembelajaran Matematika dapat dipengaruhi oleh berberapa faktor antara lain guru, suasana kelas, materi pelajaran, keluarga dan lingkungan sekolah atau dari siswa itu sendiri.Hal ini dikarenakan sebagian guru kurang memilih dan menerapkan model pembelajaran yang dapat mengaktifkan siswa dalam kegiatan belajar mengajar. Dalam kegiatan mengajar sebagian guru kurang menggunakan model pembelajaran yang bervariasi dalam penyajian materi pembelajaran Matematika sehingga pembelajaran yang dirancang selama ini membosankan dan siswa kurang aktif saat belajar.

Pemilihan model pembelajaran dalam mengajar disesuaikan dengan tingkat kebutuhan siswa, tujuan pembelajaran, materi pembelajaran agar dapat menciptakan pembelajaran yang lebih bermakna sehingga memperoleh hasil yangoptimal. Salah satu cara untuk meningkatkan hasil belajar siswa pada pembelajaranMatematika adalah menggunakan model-model pembelajaran yang bervariasi. Pada kenyataannya pemahaman sebagian guru dalam memilih atau menentukan model pembelajaran yang sesuai dengan materi pembelajaran masih kurang. Dalam menentukan model pembelajaran kita ketahui terlebih dahulu fungsi model pembelajaran antara lain sebagai 1) Pedoman yang dapat menjelaskan apa yang harus dilakukan guru, 2) Dalam pengembangan kurikulum untuk satuan dan kelas yang berbeda dalam pendidikan, 3) Penempatan bahan-bahan pengajaran yang akan digunakan oleh guru dalam membantu perubahan yang baik dari kepribadian siswa, dan 4) Perbaikan dalam mengajar untuk membantu meningkatkan keefektifan mengajar.

Begitu juga dengan media dalam mengajar. Hanya sebagian guru mengajar menggunakan media. Terutama dalam materi tentang bangun datar sebaiknya guru harus membawa contoh bentuk bangun datar agar siswa lebih paham tentang sifat-sifat bangun datar secara konkrit.

Berdasarkan hasil wawancara peneliti dengan wali kelas V-A yang sekaligus guru Matematika di SDN 068003 P.Simalingkar Medan yaitu Ibu Rusliana Saragih S.Pd dapat peneliti simpulkan bahwa rendahnya hasil belajar siswa dalam pembelajaran Matematika terlihat dengan nilai ulangan harian siswa masih tergolong rendah dan masih dibawah Kriteria Ketuntasan Minimal (KKM) yang ditentukan sekolah yaitu 65. 
Hal ini dapat dilihat hasil nilai ulangan harianMatematika pada materi sifat-sifat bangun datar di kelas V-A Tahun Pembelajaran 2017/2018 sebagai berikut:

Nilai Ulangan Harian Matematika pada Materi Sifat-sifat Bangun Datar di Kelas V SDN 068003 P. Simalingkar Medan Tahun Pembelajaran 2017/2018

\begin{tabular}{|c|c|c|c|c|}
\hline No & KKM & Nilai & Jumlah Siswa & Persentase (\%) \\
\hline 1 & 65 & $\leq 65$ & 23 & $58,9 \%$ \\
\hline 2 & 65 & $\geq 65$ & 16 & $42,1 \%$ \\
\hline \multicolumn{3}{|c|}{ Jumlah } & 39 & $100 \%$ \\
\hline
\end{tabular}

Sumber : Daftar Nilai Mata Pelajaran Matematika Kelas V SDN 068003 P.Simalingkar Medan

Dari tabel diatas dapat dilihat bahwa hasil belajar siswa kelas V-A SDN 068003 P.Simalingkar Medan Tahun Pembelajaran 2017/2018 diperoleh dari 39 siswa yang ada dalam satu ruangan kelas, siswa yang tuntas mencapai KKM hanya 16 siswa dengan persentase $(42,1 \%)$ dan yang tidak tuntas mencapai KKM sebanyak 23 siswa dengan persentase $(58,9 \%)$. Permasalahan tersebut menunjukkan bahwa rendahnya hasil belajar siswa pada pembelajaran Matematika.

Sesuai permasalahan di atas, maka perlu dilakukan peningkatan hasil belajar siswa pada pembelajaran Matematika. Makapeneliti tertarik untuk menggunakan model pembelajaran Problem Based Learningpada materi sifat-sifatbangun dataryang diharapkan dapat meningkatkan hasil belajar siswa pada proses pembelajaran secara efektif dan efisien, sehingga siswa berpikir aktif, kritis dan dapat memecahkan masalah sendiri dengan melakukan proses penyelidikan untuk mengumpulkan datapada pembelajaran Matematika.

Berdasarkan uraian tersebut, maka peneliti melakukan penelitian yang berjudul "Pengaruh Model Pembelajaran Problem Based Learning dan Model Pembelajaran KonvensionalTerhadap Hasil Belajar SiswaPada Mata Pelajaran Matematika di Kelas V SDN 068003 P.Simalingkar Medan Tahun Pembelajaran 2018/2019".

\section{Identifikasi Masalah}

Berdasarkan latar belakang masalah maka, dapat diidentifikasi beberapa permasalahan sebagai berikut :

1. Beberapa siswa masih sulit memahami materi pembelajaran Matematika 
2. Sebagian guru kurang memilih dan menerapkan model pembelajaran yang dapat mengaktifkan siswa dalam kegiatan belajar mengajar

3. Hanya sebagian guru mengajar menggunakan media

4. Rendahnya hasil belajar siswa dalam pembelajaran Matematika

\section{Batasan Masalah}

Berdasarkan identifikasi masalah yang telah dibahas diatas, permasalahan terkait penelitian ini adalah"Pengaruh Model Pembelajaran Problem Based Learningdan Model Pembelajaran Konvensional terhadap Hasil Belajar Siswapada Materi Sifat-sifat Bangun Datardi Kelas V SDN 068003 P.Simalingkar Medan Tahun Pembelajaran 2018/2019".

\section{Rumusan Masalah}

Berdasarkan batasan masalah diatas, maka rumusan masalah dalam penelitian ini adalah:

1. Bagaimana proses pelaksanaan dengan menggunakan model pembelajaran Problem Based Learningdan Model Pembelajaran Konvensional terhadap hasil belajar siswa pada pembelajaranMatematika materisifat-sifat bangun datar di kelas V SDN 068003 P.Simalingkar Medan tahun pembelajaran 2018/2019?

2. Apakah ada pengaruh model pembelajaran Problem Based Learning dan Model Pembelajaran Konvensional terhadap hasil belajar siswa pada pembelajaran Matematika materi sifat-sifat bangun datar di kelas V SDN 068003 P.Simalingkar Medantahun pembelajaran 2018/2019?

\section{Tujuan Penelitian}

Berdasarkan rumusan masalah diatas, maka tujuan penelitian ini adalah sebagai berikut:

1. Untuk mengetahui proses pelaksanaandengan menggunakan model pembelajaran Problem Based Learningdan model pembelajaran konvensional terhadap hasil belajar siswa pada pembelajaranMatematikamateri sifat-sifat bangun datar di kelas V-A SDN 068003 P.Simalingkar Medantahun pembelajaran 2018/2019.

2. Untuk mengetahui ada pengaruh model pembelajaran Problem Based Learningdan model pembelajaran konvensional dalam terhadap hasil belajar siswa pada pembelajaran Matematika materi sifat-sifatbangun datardi kelas V SDN 068003 P.Simalingkar Medantahun pembelajaran 2018/2019. 


\section{Manfaat Penelitian}

Berdasarkan tujuan penelitian diatas maka manfaat penelitian ini adalah sebagai berikut:

1. Manfaat teoritis

Hasil penelitian ini dapat memperkaya khasanah ilmu pengetahuan khususnya ilmu kajian mengenai pentingnya peranan siswa khususnya pada pembelajaran Matematika.

2. Manfaat praktis

a. Manfaat pendidik

Hasil penelitian ini menambah pengetahuan dan wawasan pendidik tentang model pembelajaranProblem Based Learning yang dapat memuculkan ide dan dapat memudahkan siswa dalam memberikan informasi dan menjawab soal tentang materi sifat-sifatbangun datar.

b. Manfaat peserta didik

Hasil penelitian ini memotivasi siswa menyukai pembelajaranMatematika pada materi sifat-sifatbangun datar.

c. Manfaat pihak sekolah

Hasil penelitian ini meningkatkan kualitas pembelajaran Matematikakhususnya pada materi sifat-sifat bangun datar.

d. Manfaat peneliti

Hasil penelitian ini dapat menambah pengetahuan dan pengalaman yang berarti sebagai bekal untuk meningkatkankualitas hasil belajar siswa pada pembelajaran Matematika.

\section{METODOLOGI PENELITIAN}

\section{Pendekatan dan Metode Penelitian}

Pendekatan yang dilakukan peneliti menggunakan pendekatan campuran yaitu dengan mengkombinasikan dua pendekatan sekaligus antara lain pendekatan kualitatif dan pendekatan kuantitatif. Adapun alasan peneliti memilih pendekatan ini karena penelitian kuantitatif berupa angka-angka, analisis menggunakan statistik, kemudian dengan melakukan wawancara atau mengobservasi guru dan siswa untuk membantu menjelaskan lebih jelas hasil statistik yang sudah diperoleh. Serta peneliti ingin mengetahui adanya pengaruh penggunaan model pembelajaran Problem Based Learning terhadap hasil belajar siswa kelas $\mathrm{V}$ pada materi sifat-sifat bangun datar. 
Metode penelitian adalah cara yang dilakukan untuk mencapai tujuan penelitian. Makin tepat metode yang digunakan makin baik pula hasil yang didapatkan. Menurut Arikunto (2017: 22) menyatakan bahwa metode penelitian merupakan struktur yang sangat penting, karena berhasil tidaknya dan rendahnya kualitas hasil penelitian sangat ditentukan oleh ketepatan dalam memilih metode penelitian.

Berdasarkan pendapat di atas maka, metode yang digunakan dalam penelitian ini adalah metodepenelitian kuantitatif. Metode ini dilakukan karena penulis ingin mengetahui ada tidaknya pengaruh penggunaan model pembelajaran Problem Based Learning terhadap hasil belajar siswa kelas V SDN 068003 P.Simalingkar Medan. Subjek penelitian yaitu seluruh siswa kelas V-A yang diberi pembelajaran menggunakan model pembelajaranProblem Based Learning dan diberi pembelajaran dengan menggunakan model pembelajaran konvensional.

\section{Lokasi dan Waktu Penelitian}

\section{Lokasi Penelitian}

Penelitian dilakukan di SDN 068003 P.Simalingkar Tahun Pembelajaran 2018/2019. Alasan peneliti memilih tempat tersebut adalah sebagai berikut:

1. Di SDN 068003 P.Simalingkar Medan belum pernah dilaksanakan penelitian dengan menggunakan model pembelajaran Problem Based Learning

2. Jumlah siswa kelas V-A SDN 068003 P.Simalingkar cukup memadai untuk dijadikan subjek penelitian yaitu 33 siswa.

3. SDN 068003 P.Simalingkar Medan adalah salah satu sekolah yang strategis serta dekat dengan tempat tinggal si peneliti.

4. Berdasarkan observasi dan data hasil belajar siswa menunjukkan bahwa hasil belajar Matematika masih rendah

\section{Waktu Penelitian}

Penelitian ini dilakukan pada semester ganjil Tahun Pembelajaran 2018/2019.

\section{Rancangan/Desain Penelitian}

Arikunto (2017:168) mengemukakan rancangan dan desain penelitian adalah rencana atau struktur penelitian yang disusun sedemikian rupa sehingga kita dapat memperoleh atas permasalahan-permasalahan penelitian. Menurut Ali \& Asrori (2014: 88) jenis penelitian yang akan digunakan oleh peneliti adalah penelitian kuasieksperimen, dimana kuasi-eksperimen ini merupakan bagian penelitian eksperimen. Kuasi eksperimen juga melibatkan kegiatan pengukuran variabel ini dimaksudkan untuk 
mengidentifikasi apakah ada pengaruh model pembelajaran Problem Based Learning terhadap hasil belajar siswa pada mata pelajaran Matematika.

Dalam penelitian ini,desain penelitian yang digunakan adalah perbandingan kelompok statis (Static Group Comparison). Penelitian ini melibatkan dua kelompok eksperimen yaitu kelompok satu (I) dan kedua (II), pada kelompok eksperimen satu diberi perlakuan dengan menggunakan Model Contextual and Teaching Learning dan kelompok eksperimen kedua menggunakan model Inkuiri.

\section{Jenis dan Sumber Data}

Data adalah sesuatu yang dapat dianalisis. Jadi, data tersebut tidak hanya berbentuk angka-angka, tetapi juga perilaku, sikap dan lain-lain. Sudijono (2012: 19) menyatakan bahwa dilihat dari datanya, maka pengumpulan data dapat menggunakan jenis data primer dan jenis data sekunder. Data primer adalah data statistic yang diperoleh atau bersumber dari tangan pertama. Data sekunder adalah data statistic yang diperoleh atau bersumber dari tangan kedua.

Menurut Arikunto (2017: 172), sumber data dalam penelitian adalah subjek dari mana data diperoleh. Sumber data dalam penelitian ini adalah siswa kelas V-A SDN 068003 P.Simalingkar Medan Tahun Pembelajaran 2018/2019, yaitu sebanyak 33 orang.

\section{Teknik dan Alat Pengumpulan Data}

Menurut Margono (2010: 158) menyatakan bahwa penggunaan teknik dan alat pengumpulan data yang tepat memungkinkan diperolehnya data yang objektif. Teknik pengumpulan data merupakan cara tertentu yang digunakan peneliti untuk mengumpulkan data sebagai hasil dari penelitiannya, dan menguji hipotesis yang telah dirumuskan. Untuk itu, teknik pengumpulan data yang dipakai harus menggunakan metode yang tepat, juga harus memilih teknik dan alat pengumpulan data yang relevan.

Dalam penelitian ini, untuk mengumpulkan data yang akan diperoleh, peneliti menggunakan teknik pengukuran berupa tes, yaitu tes pilihan berganda. Menurut Arikunto (2017: 193) tes dapat digunakan untuk mengukur kemampuan dasar dan pencapaian atau prestasi. Untuk mengukur kemampuan dasar yang dimaksud antara lain: tes untuk mengukur intelegensi (IQ), tes minat, tes bakat khusus, dan sebagainya.

Dengan demikian, langkah yang dilakukan untuk memperoleh data dengan tes akhir yang disebut post test dan alat pengumpul datanya adalah test tertulis. Menurut 
Margono (2010: 170) mengatakan bahwa tes tertulis berupa sejumlah pertanyaan yang diajukan secara tertulis tentang aspek-aspek yang ingin diketahui keadaannya dari jawaban yang diberikan secara tertulis pula. Tes yang diberikan dalam penelitian ini berupa tes pilihan pilahan berganda yaitu siswa langsung ditugasi dalam menanggapi suatu masalah dalam mengerjakan soal mengenai sifat-sifat bangun datar setelah menggunakan model pembelajaran Problem Based Learning kepada responden.

\section{Uji Instrumen Penelitian}

Dalam instrumen penelitian ini, diperlukan pilihan berganda yang dapat menjaring data. Menurut Arikunto (2017: 64) "instrumen penelitian adalah alat atau fasilitas yang digunakan oleh penelitian dalam mengumpulkan data agar pekerjaannya lebih mudah dan hasilnya lebih baik, lebih cermat, lengkap, dan sistematis sehingga lebih mudah diolah. Untuk mengetahui dan mengukur tes yang valid dan reliabel, maka peneliti menyajikan tes pilihan berganda yang berjumlah 20butir soal untuk 33 orang siswa. Tetapi peneliti akan menggunakan seluruh soal yang valid kepada seluruh subjek peneliti.

\section{Uji Validitas}

Validitas data merupakan derajat ketepatan antara data yang terjadi pada objek penelitian dengan daya yang dilaporkan oleh peneliti. Validitas berkenaan dengan ketetapan alat penilaian terhadap konsep yang dinilai sehingga betul-betul menilai apa yang seharusnya dinilai.

Untuk menguji validasi instrumen dilakukan dengan menggunakan rumus pearson/product moment, yaitu (Arikunto2017:213)

$$
\mathrm{r}_{\mathrm{XY}}=\frac{n \sum X Y-\left(\sum X\right)\left(\sum Y\right)}{\sqrt{\left(n \sum X^{2}-\left(\sum X\right)^{2}\right) \cdot\left(n \sum^{Y^{2}}-\left(\sum^{Y}\right)^{2}\right)}}
$$

keterangan :

rxy = Koefisien korelasi antara variabel $\mathrm{X}$

$\mathrm{X}=$ Skor item butir soal

$\mathrm{Y}=$ Jumlah skor total tiap soal

$\mathrm{N}=$ Jumlah responden 


\section{Uji Reliabilitas}

Reliabilitas instrumen penelitian adalah suatu alat yang memberikan hasil yang tetap sama. Untuk menguji reliabilitas tes penelitian digunakan K-R. 20 dengan rumus sebagai berikut.

Keterangan :

$$
\mathrm{R}_{11}=\left(\frac{n}{n-1}\right)\left(\frac{\mathrm{s} 2-\sum p q}{s 2}\right)(\text { Arikunto } 2017: 231)
$$

$$
\begin{array}{ll}
\mathrm{r}_{1} & =\text { Reliabilitas tes secara keseluruhan } \\
p & =\text { Proporsi subjek yang menjawab item dengan benar } \\
\mathrm{q} & =\text { Proporsi subjek yang menjawab item dengan salah }(\mathrm{q}=1-p) \\
\sum p \mathrm{q} & =\text { Jumlah hasil perkalian antara } p \text { dan } \mathrm{q} \\
\mathrm{N} & =\text { Banyaknya item } \\
\mathrm{S} & =\text { Standar deviasi dari tes (standar deviasi adalah akar varians) }
\end{array}
$$

\section{Teknik Pengolahan (Analisis Data)}

Dari pendapat di atas, maka selanjutnya data yang telah terkumpul akan dianalisis guna mencapai hasil yang maksimal. Analisis tersebut dapat dilakukan dengan langkah-langkah seperti di bawah ini. Menurut (Sudijono, 2012: 85), teknik analisis data dilakukan dengan langkah-langkah sebagai berikut:

1. Menyusun data post test dalam bentuk tabel.

2. Menghitung nilai rata-rata dan standar deviasi data sampel dari data post test.

3. Uji Normalitas

4. Uji Homogenitas

\section{Prosedur Penelitian}

Sesuai dengan jenis penelitian yang dilakukan, yaitu penelitian kuantitatif maka penelitian ini memiliki beberapa tahap pelaksanaan. Tahap-tahap yang dilakukan peneliti adalah sebagai berikut:

1. Tahap Perencanaan

Pada tahap perencanaan ini, peneliti mempersiapkan semua bahan-bahan untuk kegiatan pembelajaran yang berupa Rencana Pelaksanaan Pembelajaran (RPP), materi yang akan disampaikan atau diajarkan, dan metode yang akan digunakan.

2. Tahap Pelaksanaan

Yang perlu dilakukan dalam tahap ini adalah: 
a. Mengajarkan materi pembelajaran tentang bangun datar yaitu sifat-sifat bangun datar dengan menggunakan model pembelajaran konvensional. Dalam hal ini, yang perlu dilakukan oleh guru adalah memberi salam kepada siswa, menjelaskan tujuan pembelajaran yang akan dicapai, setelah itu, guru melakukan tanya jawab mengenai materi yang telah dijelaskan lalu disuruh mengerjakan soal-soal pada materi sifat-sifat bangun datar yang telah dipersiapkan oleh guru.

b. Mengajarkan materi pembelajaran tentang bangun datar yaitu sifat-sifat bangun datar dengan menggunakan model pembelajaran Problem Based Learning. Dalam hal ini, langkah-langkahmodel pembelajaran Problem Based Learningyang dilakukan guru adalah pada tahap orientasi siswa pada masalah, guru menjelaskan tujuan pembelajaran yang akan dicapai, siswa memikirkan sebuah permasalahan baik dalam eksperimen, mengorganisasikan siswa untuk belajar menyelidiki masalah secara bersama, membantu penyelidikan individual maupun kelompok pada siswa untuk mengumpulkan informasi dan mendorong siswa dalam memberikan ide gagasan secara bebas, menyajikan hasil masalah yang dilakukan oleh siswa, dan menganalisis serta mengevaluasi proses pemecahan masalah yang dilakukan siswa. Setelah itu, menugaskan siswa untuk menjawab soal post test yang telah dipersiapkan oleh peneliti

3. Tahap Penyelesaian

Pada tahap ini, siswa mengumpulkan lembar jawaban soal-soal sifat-sifat bangun datar. Penilaian tersebut dilakukan untuk mendapatkan hasil nilai siswa dalam bentuk post test.

\section{HASIL PENELITIAN DAN PEMBAHASAN}

Hasil Belajar Mata Pelajaran Matematika pada Materi Sifat-sifat Bangun Datar dengan Menggunakan Model Pembelajaran Konvensional

Hasil belajar mata pelajaran Matematika pada materi sifat-sifat bangun datar dengan menggunakan model pembelajaran konvensional diperoleh nilai rata-rata 64,24, berada pada kategori cukup dari 33 siswa dengan Kriteria Ketuntasan Minimal 65. Dilihat dari identifikasi kecenderungan nilai hasil yaitu nilai 80 ada 2 siswa masuk kategori baik sekali 6,06\%, nilai 70 dan 75 ada 13 siswa masuk kategori baik 39,39\%, kemudian nilai 60 dan 65 ada 10 siswa masuk kategori cukup 30,30\%, lalu nilai 50 dan 
55 ada 6 siswa masuk kategori kurang 18,18\%, dan nilai 45 ada 2 siswa masuk kategori gagal 6,06\%.

\section{Hasil Belajar Mata Pelajaran Matematika pada Materi Sifat-sifat Bangun Datar dengan Menggunakan Model Pembelajaran Problem Based Learning}

Hasil belajar mata pelajaran Matematika pada materi sifat-sifat bangun datar dengan menggunakan model pembelajaran Problem Based Learning diperoleh nilai rata-rata 80,90, berada pada kategori baik sekali dari 33 siswa dengan Kriteria Ketuntasan Minimal 65. Dilihat dari identifikasi kecenderungan nilai hasil yaitu nilai 80 sampai 100 ada 21 siswa masuk kategori baik sekali 63,63\%, lalu nilai 70 sampai 75 ada 9 siswa masuk kategori baik 27,27\%, kemudian nilai 60 dan 65 ada 3 siswa masuk kategori cukup $9,10 \%$.

\section{Pengaruh Penggunaan Model Pembelajaran Problem Based LearningTerhadap Hasil Belajar Siswa}

Hasil belajar mata pelajaran Matematika pada materi sifat-sifat bangun datar berpengaruh signifikan positif dilihat dari pengujian hipotesis yang diperoleh $t_{\text {hitung }}>\mathrm{t}_{\text {tabel }}$ 7,243 >1,67 sehingga dinyatakan bahwa $\mathrm{H}_{\mathrm{a}}$ (Hipotesis alternatif) diterima dan $\mathrm{H}_{0}$ (Hipotesis nihil) ditolak. Berdasarkan hasil tersebut keberhasilan siswa dalam materi sifat-sifat bangun datar didukung oleh penggunaan model pembelajaran yang tepat sehingga dapat meningkatkan hasil belajar siswa. Hal tersebut dapat dibuktikan dari rata-rata menggunakan model pembelajaran Problem Based Learning lebih baik dari pada model pembelajaran konvensional.

\section{PENUTUP}

\section{Simpulan}

Berdasarkan hasil dan pembahasan penelitian tentang pengaruh model pembelajaran Problem Based Learning terhadap hasil belajar siswa kelas V pada mata pelajaran Matematika di SDN 068003 P.Simalingkar Medan tahun pembelajaran 2018/2019, maka dapat disimpulkan sebagai berikut:

1. Nilai rata-rata hasil belajar dengan menggunakan model pembelajaran konvensional terhadap hasil belajar siswa pada mata pelajaran Matematika di kelas V SDN 068003 P.Simalingkar Medan Tahun Pembelajaran 2018/2019 adalah 64,24. Dilihat dari identifikasi nilai hasil yaitu nilai 80 ada 2 siswa masuk kategori baik sekali 6,06\%, nilai 70 dan 75 ada 13 siswa masuk kategori baik 39,39\%, kemudian nilai 
60 dan 65 ada 10 siswa masuk kategori cukup 30,30\%, lalu nilai 50 dan 55 ada 6 siswa masuk kategori kurang 18,18\%, dan nilai 45 ada 2 siswa masuk kategori gagal $6,06 \%$.

2. Nilai rata-rata hasil belajar dengan menggunakan model pembelajaran Problem Based Learning terhadap hasil belajar siswa pada mata pelajaran Matematika di kelas V SDN 068003 P.Simalingkar Medan Tahun Pembelajaran 2018/2019 adalah 80,90. Dilihat dari identifikasi nilai hasil yaitu nilai 80 sampai 100 ada 21 siswa masuk kategori baik sekali 63,63\%, lalu nilai 70 sampai 75 ada 9 siswa masuk kategori baik 27,27\%, kemudian nilai 60 dan 65 ada 3 siswa masuk kategori cukup $9,10 \%$.

3. Berdasarkan perhitungan hasil penelitian menunjukkan bahwa terdapat pengaruh model pembelajaran Problem Based Learning dengan model pembelajaran konvensional di SDN 068003 P.Simalingkar Medan. Hal ini dapat dilihat dari hasil analisis pengaruh dinyatakan bahwa nilai $t_{\text {hitung }}>t_{\text {tabel }}$. dimana harga $t_{\text {tabel }}$ pada taraf signifikan 5\% adalah 1,67 dan diperoleh nilai thitung 7,243. Hal ini juga dibuktikan dari nilai rata-rata model pembelajaran Problem Based Learning lebih baik dari pada model pembelajaran konvensional $(80,90>64,24)$

\section{Saran}

Berdasarkan kesimpulan dan implikasi penelitian ini maka peneliti dapat memberikan beberapa saran sebagai berikut:

1. Bagi Guru

a. Guru diharapkan dapat menerapkan model pembelajaran Problem Based Learning untuk meningkatkan hasil belajar siswa sesuai dengan materi yang diajarkan.

b. Guru hendaknya dapat menggunakan model pembelajaran yang bernilai efektif sesuai dengan materi pelajaran yang disampaikan, sehingga siswa merasa tidak dibebani oleh model ataupun metode yang menyebabkan ia merasa jenuh dan bosan ketika mengikuti kegiatan pembelajaran.

c. Selain menggunakan model pembelajaran, guru hendaknya menggunakan sumber-sumber belajar yang bervariasi dan menarik perhatian siswa

2. Bagi Peserta didik

a. Hendaknya siswa lebih giat lagi dalam belajar di ruangan kelas maupun di rumah. 
b. Siswa disarankan agar lebih efektif mengikuti kegiatan pembelajaran yang selama ini dilaksanakan

c. Siswa lebih aktif berdiskusi yang nantinya akan menambah wawasan dan ilmu pengetahuan

3. Bagi Sekolah

a. Sekolah hendaknya menyediakan fasilitas sekolah dengan lebih lengkap untuk mendorong dan meningkatkan cara belajar yang baik untuk siswa maupun guru.

b. Sekolah perlu melakukan penelitian lebih lanjut mengenai model pembelajaran Problem Based Learning di sekolah. Hal ini dapat membantu pihak skolah untuk meningkatkan dan mengetahui hasil belajar siswa.

4. Bagi peneliti

Peneliti kiranya hasil penelitian ini dapat menambah pengetahuan dan pengalaman dalam menggunakan model pembelajaran pada saat proses belajar mengajar dengan materi yang berbeda dan sampel yang berbeda.

\section{DAFTAR PUSTAKA}

Anas, Munawir. 2017. Pengaruh Penerapan Model Pembelajaran Berbasis Masalah (Problem Based Learning) Terhadap Hasil Belajar Matematika Peserta Didik Kelas IV MIN Sepabatu Kecamatan Tinambung

Ali, Asrori.2014. Metodologi dan Aplikasi Metode Penelitian. Jakarta: Bumi Aksara.

Arikunto. 2017. Prosedur Penelitian. Jakarta: Rineka Cipta.

Hamdayama, Jumanta. 2016. Metodologi Pengajaran. Jakarta : Bumi Aksara

Hamzah \& Muhlisrarini. 2016. Perencanaan dan Strategi Pembelajaran Matematika. Jakarta: Raja Grafindo Persada.

Hendriana \& Soemarmo. 2016. Penilaian Pembelajaran Matematika. Bandung: Refika Aditama

Hudojo, Herman. 2017. Pengembangan Kurikulum dan Pembelajaran Matematika. Malang: IKIP Malang

Istarani\&Pulungan. 2015. Ensiklopedia Pendidikan. Medan: Larispa.

Istarani. 2012. 58 Model Pembelajaran Inovatif.Medan: Media Persada. 
Kasri \& Gunanto. 2006. Matematika Aktif. Jakarta: Erlangga.

Kurniasih \& Sani. 2016. Ragam Pengembangan Model Pembelajaran. Yogyakarta: Kata Pena

Kusumawati, Wiwik. 2015. Penerapan Model Problem Based Learning (PBL ) pada mata pelajaran IPS Untuk Meningkatkan Hasil Belajar Siswa Pada Tema Kebutuhan Hidup di Kelas VI SD Negeri Sumboro 01 Kec.Sumboro. Jember.

Margono. 2010. Metodologi Penelitian Pendidikan. Jakarta: Rineka Cipta.

Muhsetyo, dkk. 2007. Pembelajaran Matematikan SD. Jakarta: Universitas Terbuka.

Munawari, Rayda. 2014. Meningkatkan Hasil Belajar Matematika Siswa Dengan Menggunakan Model Pembelajaran Problem Based Learning (PBL) Di Kelas IV SDN 106162 .Medan: Unimed.

Novita, Rizky 2017. Pengaruh Model Pembelajaran Problem Berbasis Masalah Terhadap Hasil Belajar Matematika Pada Siswa Kelas IV SDN Pasuruan Kecematan Penengahan. Lampung: Universitas Lampung.

Rusman. 2012. Model-Model Pembelajaran. Jakarta: Rajawali.

Siregar, Syofian.2013. Metode Penelitian Kuantitatif. Jakarta: Kencana

Sudijono. 2012. Statistik Pendidikan. Jakarta: Raja Grafindo Persada.

Sudjana. 2017. Metode Statistika. Bandung: Tarsito.

Susanto, Ahmad. 2016. Pengembangan Pembelajaran IPS di Sekolah Dasar. Jakarta : Kencana

Tampubolon. 2014. Penelitian Tindakan Kelas.Jakarta: Gelora Aksara Pratama.

Trianto. 2016. Mendesain Model Pembelajaran Inovatif-Progresif. Jakarta: Kencana.

Wimadwi. 2015.Pengaruh Model Pembelajaran Problem Based Learning (PBL) Terhadap Hasil Belajar Siswa Dalam Pembelajaran Matematika Kelas V SDN 106162 Pontianak: Universitas Jayapura. 